Article

\title{
Stumbling across the Same Phage: Comparative Genomics of Widespread Temperate Phages Infecting the Fish Pathogen Vibrio anguillarum
}

\author{
Panos G. Kalatzis ${ }^{1,2, \dagger}$, Nanna Rorbo ${ }^{1,+}$, Daniel Castillo ${ }^{1}$, Jesper Juel Mauritzen ${ }^{1}$, \\ Jóhanna Jørgensen ${ }^{1}$, Constantina Kokkari ${ }^{2}$, Faxing Zhang ${ }^{3}$, Pantelis Katharios ${ }^{2}$ and \\ Mathias Middelboe ${ }^{1, *}$ \\ 1 Marine Biological Section, University of Copenhagen, DK-3000 Helsingør, Denmark; \\ panos.kalatzis@bio.ku.dk (P.G.K.); nanna.rorbo@bio.ku.dk (N.R.); danielcastillobq@gmail.com (D.C.); \\ kcq442@alumni.ku.dk (J.J.M.) ; johannajorgensen88@gmail.com (J.J.); \\ 2 Institute of Marine Biology, Biotechnology and Aquaculture, Hellenic Centre for Marine Research, \\ Crete 71500, Greece; dkok@hcmr.gr (C.K.); katharios@hcmr.gr (P.K.) \\ 3 Beijing Genomics Institute (BGI) Park, No.21 Hongan 3rd Street, Building NO. 7, Yantian District, \\ Shenzhen 518083, China; jason.zhang@genomics.cn \\ * Correspondence: mmiddelboe@bio.ku.dk; Tel.: +45-3532-1991 \\ + The two first co-authors contributed equally to this work.
}

Academic Editor: Eric O. Freed

Received: 1 March 2017; Accepted: 12 May 2017; Published: 20 May 2017

\begin{abstract}
Nineteen Vibrio anguillarum-specific temperate bacteriophages isolated across Europe and Chile from aquaculture and environmental sites were genome sequenced and analyzed for host range, morphology and life cycle characteristics. The phages were classified as Siphoviridae with genome sizes between 46,006 and 54,201 bp. All 19 phages showed high genetic similarity, and 13 phages were genetically identical. Apart from sporadically distributed single nucleotide polymorphisms (SNPs), genetic diversifications were located in three variable regions (VR1, VR2 and VR3) in six of the phage genomes. Identification of specific genes, such as N6-adenine methyltransferase and lambda like repressor, as well as the presence of a tRNA ${ }^{\mathrm{Arg}}$, suggested a both mutualistic and parasitic interaction between phages and hosts. During short term phage exposure experiments, $28 \%$ of a $V$. anguillarum host population was lysogenized by the temperate phages and a genomic analysis of a collection of 31 virulent $V$. anguillarum showed that the isolated phages were present as prophages in $>50 \%$ of the strains covering large geographical distances. Further, phage sequences were widely distributed among CRISPR-Cas arrays of publicly available sequenced Vibrios. The observed distribution of these specific temperate Vibriophages across large geographical scales may be explained by efficient dispersal of phages and bacteria in the marine environment combined with a mutualistic interaction between temperate phages and their hosts which selects for co-existence rather than arms race dynamics.
\end{abstract}

Keywords: bacteriophages; temperate; Vibrio anguillarum; Siphovirus; genetic similarity; omnipresent; lysogenic conversion.

\section{Introduction}

Vibrios are a genetically and metabolically diverse group of marine heterotrophic bacteria that plays significant roles in marine biogeochemical cycling [1]. The genus is globally distributed in marine and brackish environments and occurs as both free-living and surface-associated communities ranging from coastal areas to the open sea [1-3]. The group contains several pathogens, including Vibrio anguillarum, which infects more than 50 species of fish, mollusks and crustaceans, causing 
vibriosis [4], a devastating disease affecting the aquaculture industry worldwide. V. anguillarum consists of both pathogenic and non-pathogenic strains [5,6], and the mechanism of pathogenesis of $V$. anguillarum is not completely understood yet. Recent advancements in genome sequencing have started to shed light in putative bacterial virulence and fitness factors including exotoxins, adherence/colonization proteins, invasion, capsule and cell surface components as well as iron uptake system $[7,8]$.

Virulence in Vibrios can also be associated with the expression of prophage-encoded genes through the process of lysogenic conversion [9-11]. A well-known example of prophage generated virulence is the human pathogen $V$. cholerae, in which the key toxins (CTX and Zot) are encoded by specific prophages $[12,13]$. More recently, these prophage-associated toxins have also been identified in environmental Vibrios (e.g., V. coralliilyticus), indicating that prophage-encoded genes are disseminated between environmental Vibrio populations [14]. In addition, in the fish pathogen $V$. harveyi, the prophage VHML conferred virulence by lysogenic conversion $[15,16]$ and recent bioinformatic analyses have identified numerous phage genes potentially encoding virulence and fitness factors in environmental Vibrio strains $[14,17]$. Therefore, there is increasing evidence that lysogenic conversion plays a significant role in shaping environmental Vibrio populations contributing to their functional and genetic diversity. In addition to lysogenic conversion, prophages can also affect host properties by serving as anchor points for genomic rearrangements [18], by disrupting critical genes or operons during integration and excision [19] and by preventing infection by similar phages with superinfection exclusion mechanisms [20]. Further, phage-derived bacterial immunity can be obtained by phage-encoded interactions with restriction-modification (RM) system, such as expression of methyltransferases [21,22].

The presence of prophages in marine bacteria has also been connected with more subtle benefits for the bacterial host. Marine prophages can suppress unneeded metabolic activities of their host under unfavorable environmental conditions, serving as energy saving and survival enhancing tool [23]. Thus, Vibrio prophages and temperate phages constitute potentially a major reservoir of functional traits in the marine environment, including virulence. The mobilization of these phage-encoded properties may be a key driving force for dissemination of such properties in environmental marine Vibrio communities.

Bacteriophages can display biogeographical patterns following their hosts' geographical patterns [24] and both cosmopolitan phages with a worldwide distribution [25], and phages constrained to a specific environment have been observed $[9,26]$. Previous studies have found indications that populations of genetically related vibriophages are widely distributed over large geographic distances in the oceans [27]. However, little is known about the geographical distribution of specific vibriophages. The diversity of bacteriophages can be high when examined locally but when a more global approach is attempted, diversity can be relatively limited due to the phages ability move among different biomes [27-29].

Studies on V. anguillarum-specific bacteriophages have so far mainly focused on lytic phages and their potential use in phage therapy application [30-32] while very little is known about the role of temperate phage-encoded virulence and other fitness factors as drivers of functional dynamics in $V$. anguillarum. Improving our understanding of how phages may influence the genomic and phenotypic characteristics of $V$. anguillarum thus requires more detailed knowledge of the genetic properties and dispersal of temperate phages infecting this pathogen as well as their distribution as prophages in the host community.

In this study, we report the complete nucleotide sequences, annotations and genome comparison of 19 V. anguillarum-specific temperate bacteriophages isolated from Denmark, Norway, Greece and Chile using both aquaculture and environmental sites. Further, we analyze the distribution of the temperate phages as prophages in a collection of 31 virulent $V$. anguillarum strains and test their ability to lysogenize $V$. anguillarum. The bacteriophage sequences were mapped against the available CRISPR-Cas arrays of the Vibrio genus in order to assess past events of phage-bacterial interactions 
leading to spacer acquisition. The geographical distribution and genomic characterization, along with the phage morphology, host range and kinetic parameters of selected phages unraveled a novel insight into a group of temperate phages, designated H20-like phages and their potential for lysogenic conversion and interactions with $V$. anguillarum across large spatial scales.

\section{Materials and Methods}

\subsection{Bacterial Strains and Growth Conditions}

The V. anguillarum strains A023, T265, BA35 and VaKef were used as hosts for bacteriophage isolation. The host strains are part of a V. anguillarum collection, which consists of 31 well characterized and whole genome sequenced strains [33]. All bacterial strains were stored at $-80{ }^{\circ} \mathrm{C}$ in Luria-Bertani (LB) medium (Invitrogen, Carlsbad, CA, USA) supplied with 15\% glycerol. For proliferation, the strains were inoculated in LB medium and incubated at $25^{\circ} \mathrm{C}$ with constant agitation.

\subsection{Isolation, Purification and Propagation of Bacteriophages}

More than 100 aquaculture and environmental marine water samples have been collected from Denmark, Norway, Greece and Chile and isolation of phages was performed using standard enrichment methodology [34] with minor modifications. The bacterial strains used for phage isolation were added separately to the water samples, supplemented with $10 \%$ LB medium. Samples were incubated overnight at $25^{\circ} \mathrm{C}$ with constant agitation, following centrifugation at $6000 \times g$ for $10 \mathrm{~min}$. Supernatants were filtered through $0.22 \mu \mathrm{m}$ syringe filters (Whatman, Maidstone, UK) and the presence of phages was examined with plaque assay using the double-layer agar method [35]. Briefly, $100 \mu \mathrm{L}$ filtrate was added to $300 \mu \mathrm{L}$ liquid cultures of each of the bacterial strain that were used for phage isolation. The mixture was then added to $4 \mathrm{~mL}$ melted soft agar $(0.4 \%$ agar and $1 \%$ sea salts (Sigma-Aldrich, Saint Louis, MO, USA)) and poured onto LB 1.5\% agar plates. Following overnight incubation at $25^{\circ} \mathrm{C}$, the plates were inspected for plaque forming units (pfu) on the host bacterial lawn. Single phage plaques were picked and purified by $5 \times$ re-plating. In this way, 19 clonal phage isolates were obtained from individual water samples (Table 1). Proliferation of bacteriophage isolates was conducted in $50 \mathrm{~mL}$ LB medium, by mixing the bacterial host strain at its early exponential phase with the corresponding bacteriophages at a multiplicity of infection (MOI) of 10, and incubating the mixture overnight at $25^{\circ} \mathrm{C}$ with constant agitation. Following centrifugation and filtration through $0.22 \mu \mathrm{m}$ syringe filters, the 19 final bacteriophage stocks were titered and stored at $4{ }^{\circ} \mathrm{C}$.

Water samplings did not require any special permission.

\subsection{Morphology, Life Cycle and Host Range of Bacteriophages}

Virion morphology of two of the H20-like bacteriophages, $\phi$ VaK and pVa-7, was determined under Transmission Electron Microscopy (TEM) observation at the facilities of University of Crete, Greece. Samples were prepared on collodium copper grids, negatively contrasted with $2 \%$ uranyl acetate, and examined by JEOL JEM2100 electron microscope at $80 \mathrm{kV}$, applying instrumental magnification of 120,000 . The morphology of the phages (H20 and H8) was determined previously [36].

One-step growth experiments were performed with $\phi \mathrm{H} 20, \mathrm{pVa}-3, \phi C L A$ and $\phi \mathrm{P} 3$ by adding the phages to $1 \mathrm{~mL}$ of their bacterial host $V$. anguillarum strain BA35 (MOI:0.001) at early exponential phase in LB medium and incubating at $25{ }^{\circ} \mathrm{C}$ for $15 \mathrm{~min}$. Following centrifugation at $6000 \times g$ for $10 \mathrm{~min}$, supernatants containing free, unattached phages were discarded, while phages which had attached to the bacterial hosts were pelleted. The bacterial cells were then resuspended in $20 \mathrm{~mL}$ medium containing 1\% Tryptone (Difco, Livonia, MI, USA), 0.5\% Yeast extract (Difco), and 2\% sea salts (Sigma-Aldrich). Setting that time point as $\mathrm{t}=0,20 \mu \mathrm{L}$ drops of serial dilutions were spotted on bacterial lawns prepared on LB agar plates every $10 \mathrm{~min}$ for total duration of $130 \mathrm{~min}$. Plaque forming units in the spotted areas were counted after overnight incubation at $25^{\circ} \mathrm{C}$. One-step curves were plotted from 3 individual experiments performed for each of the 4 bacteriophages assayed. 
Phage adsorption was evaluated for $\phi \mathrm{H} 20, \mathrm{pVa}-3, \phi \mathrm{Cla}$ and $\phi \mathrm{P} 3$, using 6-well plates each containing $3 \mathrm{~mL}$ of $V$. anguillarum strain BA35 liquid culture at early exponential phase of growth in LB medium. Each bacteriophage tested was added to 3 wells (triplicates) applying a MOI of 0.001 . Samples of $200 \mu \mathrm{L}$ were collected every $5 \mathrm{~min}$, followed by centrifugation at 10,000 $\times g$ for $2 \mathrm{~min}$. Drops of $20 \mu \mathrm{L}$ containing un-adsorbed phages were taken from the supernatant and spotted on the host bacterial lawn as above. The total duration of the experiment was $30 \mathrm{~min}$ and plaque forming units were counted after overnight incubation at $25^{\circ} \mathrm{C}$. The phage adsorption constant was calculated from the decrease in the free, unattached phages over the incubation period $[37,38]$.

The lytic spectrum (host range) of the isolated bacteriophages was assessed by spotting them on the bacterial lawns of the $31 \mathrm{~V}$. anguillarum pathogenic strains collection. Twenty-microliter drops of each phage concentrate were spotted in triplicate on bacterial lawns followed by overnight incubation at $25^{\circ} \mathrm{C}$.

\subsection{DNA Extraction and Sequencing}

DNA was extracted from all 19 isolated bacteriophages using high titer samples $\left(10^{10} \mathrm{pfu} \cdot \mathrm{mL}^{-1}\right)$. The viral particles were concentrated by adding poly-ethylene glycol to the $4{ }^{\circ} \mathrm{C}$ phage stocks, followed by centrifugation $(20,000 \times g, 1 \mathrm{~h})$ and resuspension of the phage pellet in $100 \mu \mathrm{L}$ of $\mathrm{NaCl}$ solution (150 mM). QIAamp DNA Blood Mini Kit (QIAGEN, Hilden, Germany) was used for the bacteriophage genome extraction, according to the manufacturer's protocol. The concentration of phage DNA was quantified by NanoDrop (Thermo Fisher Scientific, Waltham, MA, USA) and the DNA quality was assessed in an agarose gel.

Genome sequencing for all isolated bacteriophages was conducted using Illumina Hi Seq 2000 sequencer (Illumina, San Diego, CA, USA) at Beijing Genomic Institute (Shenzhen, Guangdong, China) using pair-end read sizes of $100 \mathrm{bp}$. Sequencing process, library construction and trimming of contaminated reads and primers, were performed in accordance with the manufacturer's protocols. De novo assembly of the produced reads was done by Geneious algorithm, with Geneious software bioinformatics platform R9 version [39], resulting in single contigs for all phages. Short and low-coverage contigs were discarded.

\subsection{Annotation, Comparative Genomics, and Phylogeny}

The genes of the sequenced bacteriophages were predicted by Glimmer 3 [40] and the open reading frames (ORFs) were generated. Annotations of the genes were performed automatically by Rapid Annotation Subsystem Technology (R.A.S.T.) [41,42]. Both annotated ORFs and hypothetical proteins ORFs that represented coding sequences (CDSs), were crosschecked manually by protein Basic Local Alignment Tool (BLASTP) and by Protein Fold Recognition Server, Phyre ${ }^{2}$ [43,44], defining the gene functions both by genetic similarity and by protein structure. The presence of tRNA was assessed by the online tool ARAGORN [45]. Alignment of whole viral genomes was conducted by progressive MAUVE algorithm [46] using the Geneious software bioinformatics platform [39]. The direct terminal repeats (DTR) that were detected at the right and left ends of each phage contig marked the physical ends of the phage genomes (151 bp for $\phi \mathrm{VaK}$ and $143 \mathrm{bp}$ for the rest phages). Additionally, attL and attR were characterized by the sequence TCGTGATTCCTTGC(T)CACCG CCACATCCAAGCCTCTTG(A)GGTATCAAGAGGCTTTATTTTATCTGACAGACCCCGCAAT(T) and direction of all sequences is attL $\rightarrow$ attR. Phylogenetic analyses of both the isolated phages and the $V$. anguillarum prophages included in the study, were conducted by Geneious Tree Builder, using Neighbor-Joining method and Tamura-Nei genetic distance model (1000 bootstraps).

\subsection{CRISPR Arrays and Prophage Detection in Vibrio}

All publicly available Vibrio genomes and downloaded from the National Center for Biotechnology Information (NCBI) GenBank [47]. The presence of CRISPR arrays in the Vibrio genomes was evaluated in 1185 genomes representing 64 different Vibrio species, using CRISPR Finder online tool [48]. Further, 
potentially inducible intact prophages were detected in the genomes of our V. anguillarum collection [34] using the online prophage finder tool, PHAST [49].

\subsection{Integration of Phages in V. anguillarum Strain BA35}

The ability of the isolated temperate phages to integrate into the bacterial host's genome was evaluated by coculturing $V$. anguillarum strain BA35 with $\phi \mathrm{H} 20$. Triplicate bottles with $48 \mathrm{~mL} \mathrm{LB}$ medium were inoculated with the addition of host strain BA35 and $\phi \mathrm{H} 20$ (MOI: 50), incubated at $25^{\circ} \mathrm{C}$ for $12 \mathrm{~h}$ with agitation. Bacterial growth was monitored by measuring optical density at $600 \mathrm{~nm}\left(\mathrm{OD}_{600}\right)$ every hour using Novaspec Plus Visible Spectrophotometer (Amersham Biosciences, Uppsala, Sweden). Exponential growth was observed after 10-12 h of incubation and triplicates of $1 \mathrm{~mL}$ were sampled and serially diluted in SM buffer (Sodium Magnesium; $100 \mathrm{mM} \mathrm{NaCl}, 8 \mathrm{mM} \mathrm{MgSO}_{4} \cdot 7 \mathrm{H}_{2} \mathrm{O}, 50 \mathrm{mM}$ Tris-Cl, $0.01 \%$ gelatin, $\mathrm{pH}:$ 7.5). Dilutions were poured onto LB agar plates and the following day, 50 bacterial colonies were isolated and recultured at $25^{\circ} \mathrm{C}$. The ability of the bacteriophage $\phi \mathrm{H} 20$ to lysogenize its host was assessed by Polymerase Chain Reaction (PCR) with 3 sets of specific primers (Supplementary Table S1). They were able to target and propagate 3 specific phage genes: a structural tail protein gene, a terminase large subunit gene and a hypothetical protein gene. All 50 isolated bacterial strains were washed 5 times with SM buffer in order to eliminate the possibility of a false positive reaction caused by any remnant phage particles. A triple positive PCR would confirm the lysogenization.

\subsection{GenBank Accession Numbers}

The GenBank accession numbers for the new sequenced bacteriophages are: KX581090, KX581091, KX581092, KX581093, KX581094, KX581095, KX581096, KX581097, KX581098, KX581099, KX581100, KY658673, KY658674, KY658675, KY658676, KY658677, KY658678, KY658679, and KY658680. Since all 19 phages were genetically similar, they were designated as H20-like phages named after $\phi \mathrm{H} 20$, which was isolated and described as the first [36].

\section{Results}

\subsection{Isolation and Characterization of Bacteriophages}

Sixteen bacteriophages were isolated in the current study using two $V$. anguillarum strains as hosts: strain BA35 ( $\phi \mathrm{P} 2, \phi \mathrm{P} 3, \mathrm{pVa}-1, \mathrm{pVa}-2, \mathrm{pVa}-3, \mathrm{pVa}-4, \mathrm{pVa}-5, \mathrm{pVa}-6, \mathrm{pVa}-7$, pVa-8, $\phi C L A, \phi \mathrm{Her}$, $\phi$ Len, $\phi \mathrm{Pel}$ and $\phi$ Strym) and strain VaKef $(\phi \mathrm{VaK})$. Further, three phages were isolated in a previous study [36] using three different hosts: BA35 ( $\phi \mathrm{H} 20)$, T265 ( $\phi \mathrm{H} 8)$ and A023 $(\phi \mathrm{H} 2)$. None of the used host strains contained H20-like prophages, implying that the isolated phages originated from the water samples. All phages produce similar $1 \mathrm{~mm}$ plaques on their host bacterial lawns. They were isolated from four different countries (Denmark, Norway, Greece and Chile), both from aquaculture and environmental marine water samples. Their genome sizes ranged between 46,006 and 54,201 base pair (bp) with a similar GC content of $43 \%-43.1 \%$ and with a number of ORFs between 76 and 94 (Table 1). 
Table 1. Genomic information about the 19 sequenced bacteriophages of the current study. The bacteriophages were isolated against four different clinical Vibrio anguillarum strains (A023, T265, BA35, and VaKef). DK: Denmark, N: Norway, GR: Greece, CL: Chile, Aq: Aquaculture. M: Marine environment.

\begin{tabular}{|c|c|c|c|c|c|c|c|}
\hline Bacteriophages & Origin & Environment & $\begin{array}{l}\text { Host } \\
\text { Strain }\end{array}$ & $\begin{array}{l}\text { Genome } \\
\text { Size (bp) }\end{array}$ & $\begin{array}{c}\text { GC Content } \\
(\%)\end{array}$ & ORFs & $\begin{array}{c}\text { GenBank } \\
\text { Accession } \\
\text { Number }\end{array}$ \\
\hline$\phi \mathrm{H} 2$ & DK & $\mathrm{Aq}$ & A023 & 46,149 & 43.1 & 76 & KY658673 \\
\hline$\phi \mathrm{H} 8$ & DK & $\mathrm{Aq}$ & T265 & 46,157 & 43.1 & 76 & KY658674 \\
\hline$\phi \mathrm{H} 20$ & DK & $\mathrm{Aq}$ & BA35 & 53,224 & 43 & 91 & KY658675 \\
\hline$\phi \mathrm{P} 2$ & $\mathrm{~N}$ & $\mathrm{Aq}$ & BA35 & 46,149 & 43.1 & 76 & KY658676 \\
\hline$\phi \mathrm{P} 3$ & $\mathrm{~N}$ & $\mathrm{Aq}$ & BA35 & 53,242 & 43 & 91 & KY658677 \\
\hline pVa-1 & GR & M & BA35 & 53,227 & 43.1 & 91 & KX581095 \\
\hline pVa-2 & GR & M & BA35 & 53,286 & 43 & 91 & KX581094 \\
\hline pVa-3 & GR & M & BA35 & 54,344 & 43.1 & 94 & KY658678 \\
\hline pVa-4 & GR & M & BA35 & 54,295 & 43.1 & 93 & KY658679 \\
\hline pVa-5 & GR & M & BA35 & 53,227 & 43 & 91 & KX581096 \\
\hline pVa-6 & GR & M & BA35 & 53,2274 & 43 & 91 & KX581097 \\
\hline pVa-7 & GR & M & BA35 & 54,268 & 43.1 & 93 & KX581110 \\
\hline pVa-8 & GR & M & BA35 & 53,227 & 43 & 91 & KY658680 \\
\hline$\phi C L A$ & CL & M & BA35 & 53,226 & 43 & 91 & KX581091 \\
\hline$\phi$ Her & GR & M & BA35 & 53,226 & 43 & 91 & KX581090 \\
\hline$\phi$ Len & GR & M & BA35 & 53,226 & 43 & 91 & KX581092 \\
\hline$\phi$ Pel & GR & M & BA35 & 53,227 & 43 & 91 & KX581093 \\
\hline$\phi$ Strym & GR & M & BA35 & 53,226 & 43 & 91 & KX581099 \\
\hline$\phi \mathrm{VaK}$ & GR & $\mathrm{Aq}$ & VaKef & 53,216 & 43 & 92 & KX581098 \\
\hline
\end{tabular}

In addition to the genomic characterization, a selection of the H20-like phages group was further analyzed for virion morphology and life cycle parameters. The observed morphology of the virions under TEM classified the bacteriophages to the Siphoviridae family. Virions had a long, non-contractile tail of about $150 \mathrm{~nm}$ and a head of approximately $50 \mathrm{~nm}$ in diameter (Figure 1).

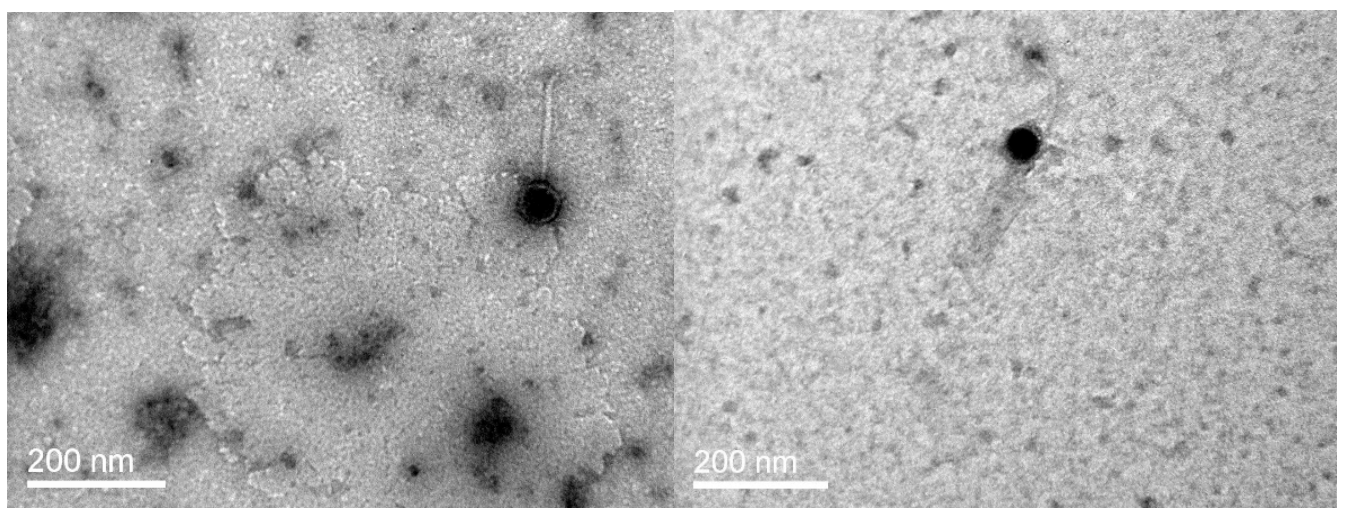

Figure 1. Transmission electron microscopy micrographs of bacteriophages: $\phi V a K$ (left); and pVa-7 (right) classifying them to Siphoviridae family.

One-step growth and phage adsorption curves have been generated to determine the life cycle parameters of the bacteriophages (Supplementary Figure S1A,B). Latency time, burst size and adsorption constant ranged from 50 to $70 \mathrm{~min}, 100$ to 145 virions per cell and $8.6 \times 10^{-8}$ to $1.2 \times 10^{-7}$, respectively (Table 2). 
Table 2. Kinetic parameters (latency time, burst size and adsorption constant) of the bacteriophages $\phi \mathrm{H} 20$, pVa-3, $\phi C L A$ and $\phi P 3$. All values are means \pm standard deviation of three independent experiments.

\begin{tabular}{cccc}
\hline Bacteriophage & Latency Time (min) & Burst Size (Virions/Cell) & Adsorption Constant $\mathbf{K}_{\mathbf{3 0}}$ \\
\hline$\phi \mathrm{H} 20$ & 60 & $112 \pm 9$ & $1.18 \times 10^{-7} \pm 1.28 \times 10^{-8}$ \\
pVa-3 & 60 & $100 \pm 13$ & $8.63 \times 10^{-8} \pm 2.46 \times 10^{-9}$ \\
$\phi \mathrm{P} 3$ & 70 & $101 \pm 16$ & $6.40 \times 10^{-8} \pm 4.39 \times 10^{-9}$ \\
$\phi \mathrm{Cla}$ & 50 & $145 \pm 24$ & $2.11 \times 10^{-7} \pm 2.68 \times 10^{-8}$ \\
\hline
\end{tabular}

\subsection{Host Range Analysis and Phylogeny}

Thirty-one pathogenic strains of V. anguillarum were used to determine the lytic spectrum of the 19 bacteriophage isolates (Figure 2). Seventeen out of 19 phages had almost identical host range with only one minor difference in the case of $\phi \mathrm{H} 8$. Two phages showed a different host range: $\phi \mathrm{H} 2$ only infected strain A023, whereas bacteriophage $\phi \mathrm{VaK}$ had a broader host range and infected eight out of 31 bacterial strains tested. According to the phylogenetic analysis of the 19 isolated bacteriophages, $\phi \mathrm{P} 3, \phi \mathrm{H} 8, \phi \mathrm{P} 2, \phi \mathrm{H} 2$ and $\phi \mathrm{VaK}$ had a higher number of substitutions per site. The combined host range table and the phylogenetic tree of the bacteriophages (Figure 2) indicated that the differences in the lytic spectrum are accompanied by differences at the genetic level. Especially in the case of $\phi V a K$, where most genetic differences are observed, the lytic spectrum is much broader than the others. 


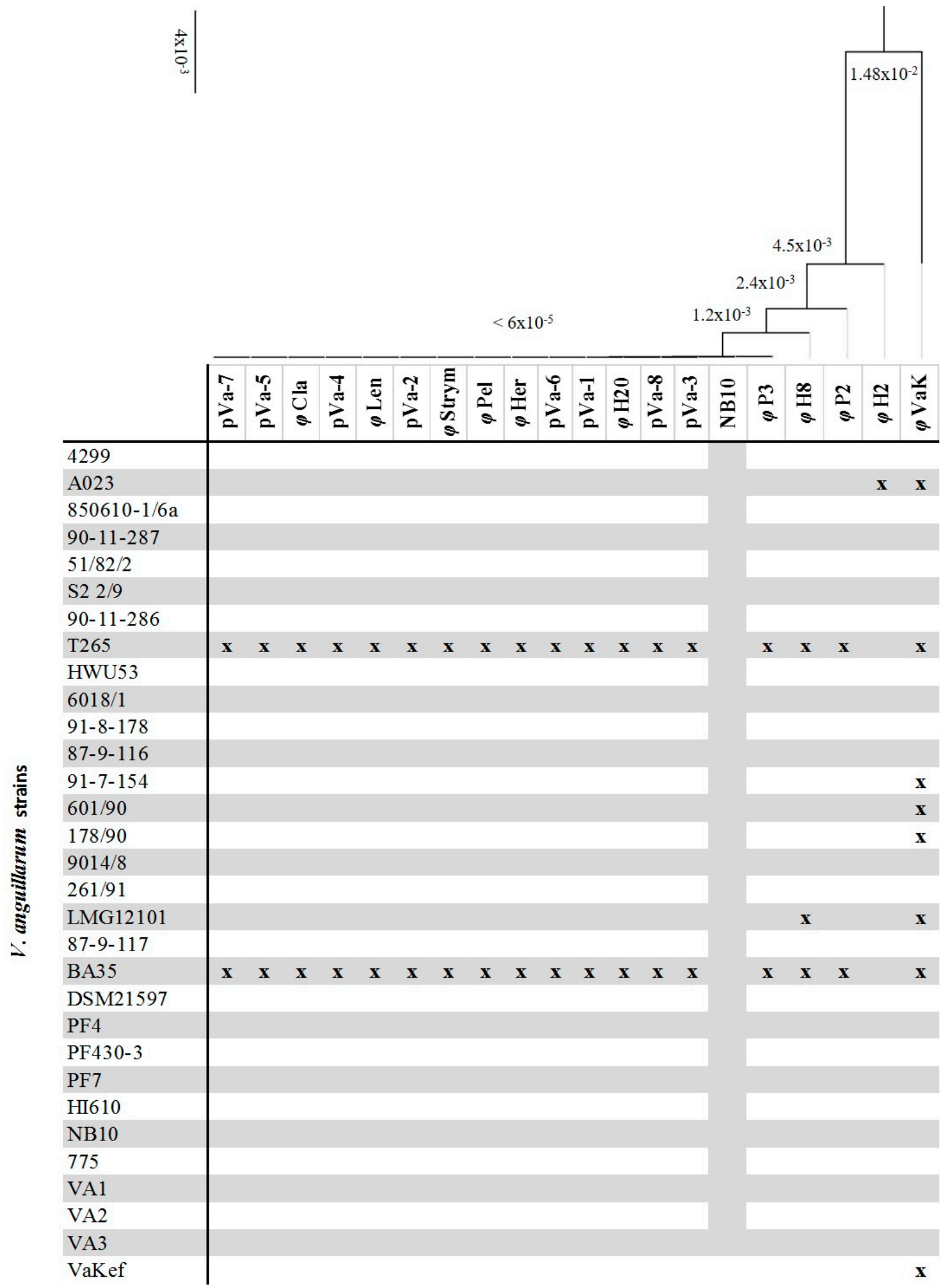

Figure 2. Host range of the 19 bacteriophage isolates against 31 pathogenic $V$. anguillarum strains. Blocks marked with $x$, indicate the infection of the bacteria by the corresponding bacteriophage isolate. The phylogenetic tree based on the whole genomes of the 19 sequenced phages of the current study (Neighbor-Joining method). The prophage from V. anguillarum strain NB10 was included as a reference phage. The branch labels indicate the substitutions per site. 


\subsection{Comparative and Functional Phage Genomics}

The genomes of all 19 bacteriophages closely resemble a prophage genome which is present in the Vibrio anguillarum strain NB10 (GenBank No. LK021130) [50]. Additionally, H20-like bacteriophages were also found to be a part of several $V$. anguillarum genomes that have been recently released in the NCBI GenBank [34]. However, genomic comparisons of the phages have revealed some differences at the genetic level, which are depicted in an aligned sequence graph (Figure 3).

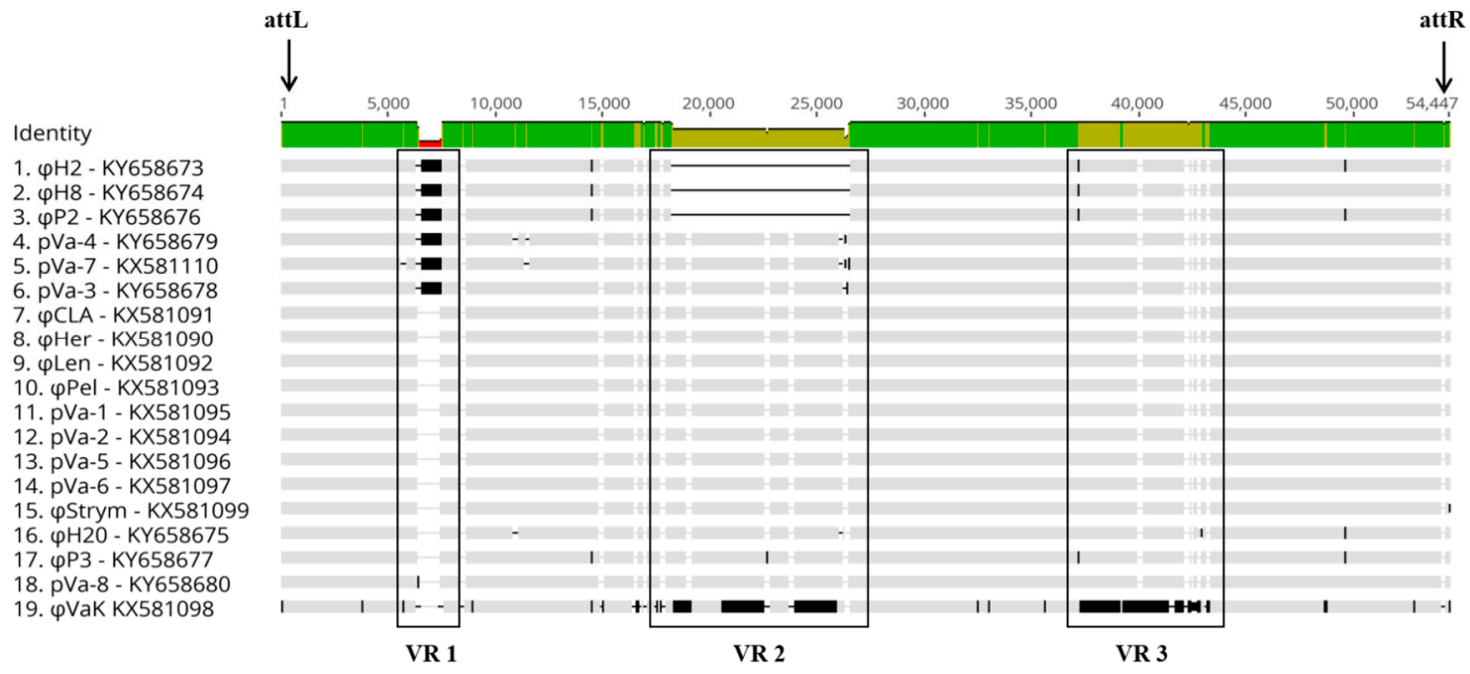

Figure 3. Genomic alignment of the 19 newly sequenced temperate bacteriophages. The black boxes indicate the variable regions (VR 1, VR 2 and VR 3). Single nucleotide polymorphisms (SNPs) and genetic differences are found sporadically in the genomes as black vertical lines either thin or thick depending on the length of the differences. Genome gaps are depicted with the black horizontal lines. The physical ends of the genomes are indicated by direct terminal repeats (DTRs) following the direction of attL $\rightarrow$ attR.

SNPs are sporadically distributed through the 19 phage genomes. However, there are three variable regions, named VR1, VR2 and VR3, which show systematic modifications among phages (Figure 3). In phages $\phi \mathrm{P} 2, \phi \mathrm{H} 8$ and $\phi \mathrm{H} 2$, the biggest part of $\mathrm{VR} 2$ is completely missing, whereas VR1 is only present in phages $\phi \mathrm{P} 2, \phi \mathrm{H} 8, \phi \mathrm{H} 2, \mathrm{pVa}-3, \mathrm{pVa}-4$ and $\mathrm{pVa}-7$. As a result of these genomic modifications, the $\mathrm{H} 20$-like bacteriophages demonstrate a range of genome sizes, between $46-\mathrm{kb}$ and 54-kb (Table 1).

Apart from the presence/absence of VR1 and VR2, most of the phages are genetically homogenous with the exception $\phi \mathrm{VaK}$, where both VR1 and VR3 are very diverse compared to all other phage genomes, while VR1 is missing. SNPs in the genome of $\phi \mathrm{VaK}$ are also more frequent compared to the other bacteriophages. These genomic differences seem to be reflected in the phage's phenotype, since the host range of this phage is much broader than the others (Figure 2).

For most of the genes in the H20-like phages, the function remains unknown. However, taking into consideration both the genetic similarity and the protein folding structure of the viral gene products, it was possible to define the predicted function of approximately one third of the viral genes. The viral genes were predicted and then annotated based on their genetic similarity with the NCBI GenBank database, mainly referring to the prophage of strain NB10 annotation. Additional information on gene function that came from their protein folding pattern, determined by amino acid composition, contributed significantly in complementing the annotation of the bacteriophages. Thus, 15 gene functions and protein families were attributed to the one third of the viral genes, with structural and DNA binding proteins being mostly represented. Seventy-four genes compose the core-gene content of all 19 bacteriophages and this is the common basis on which accessory genes are 
added in some of the phage genomes (Figure 4). These 74 genes encode all the structural proteins, most of the DNA binding proteins and hydrolases and all the proteins related to regulation of gene expression, biosynthesis and metabolism, peptidase and lysozyme activity, ribonuclease activity, $\mathrm{HNH}$ endonucleases, RNA binding and DNA repairing. The presence of an integrase gene suggests that the H20-like bacteriophages are temperate phages able to be integrated in their host's genome, as it has happened in the case of the V. anguillarum NB10 prophage. Repressor, integrase, methyltransferase and RNA $^{\mathrm{Arg}}$, are also part of the core gene content present in all 19 bacteriophages. The core genome thus supports the functionality of the H20-like bacteriophages. However, 21 different accessory genes are present in some of the bacteriophage genomes. VR1 and VR2 are the main genomic parts of the accessory genome since they possess two and 17 genes, respectively. VR1 has a transposase and a putative 5-methycytocin specific restriction enzyme and VR2 has 13 genes of unknown function, two hydrolase, one DNA binding and one lysozyme activity proteins (Figure 4). The presence of accessory genes was not associated with any of the measured phenotypic properties.

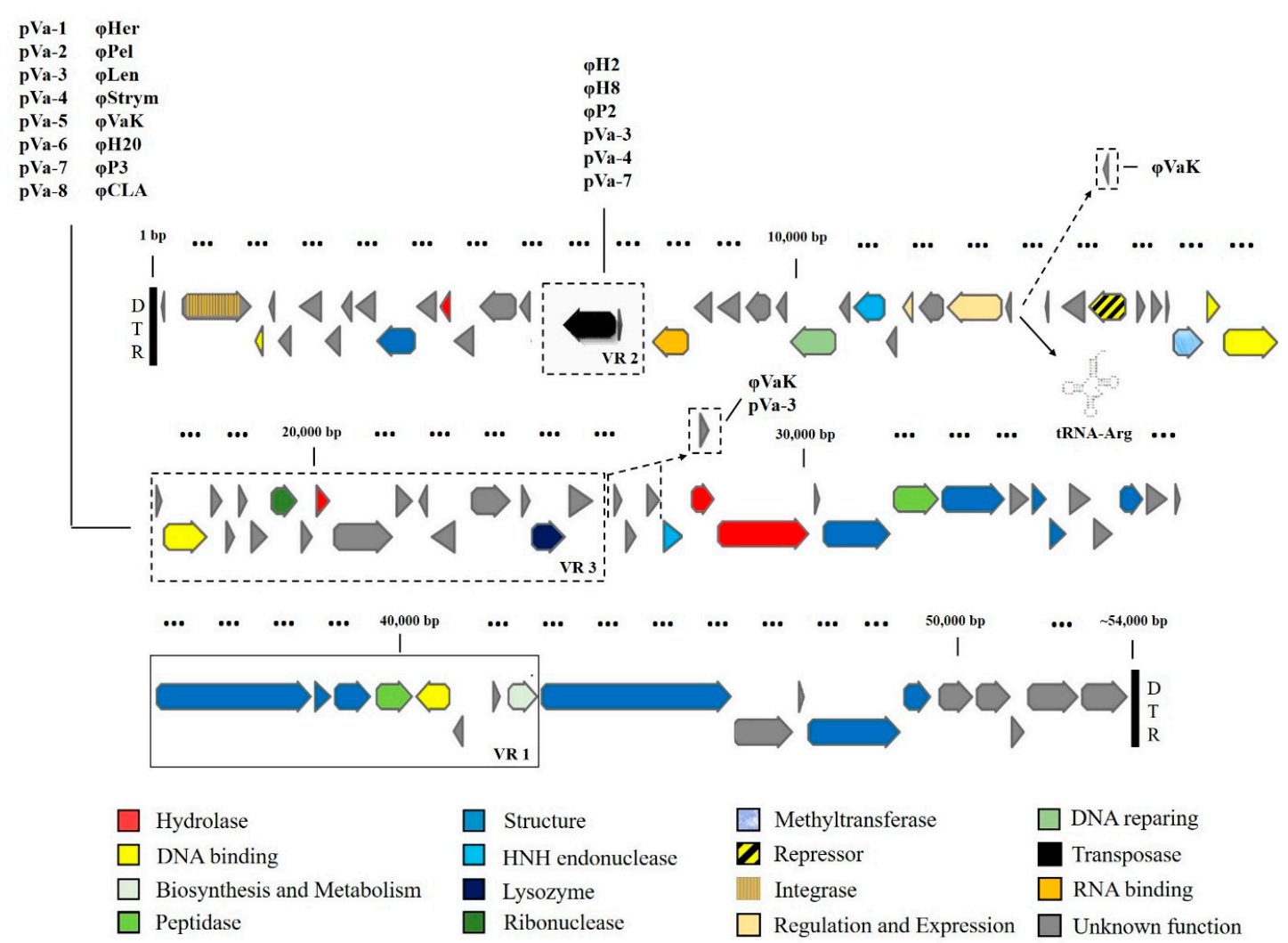

Figure 4. The core- and accessory- gene content of the H20-like bacteriophages. Core-gene content is composed by 74 genes shared by all 19 bacteriophages. Accessory-gene content is indicated by dashed lines, with VR1 and VR2 representing the main components. The bacteriophages that contain the accessory gene blocks VR1 and/or VR2 are correspondingly indicated in columns beside. Two more hypothetical proteins complement the accessory gene content and their corresponding carrier phages (pVa-3 and $\phi \mathrm{VaK}$ ) are also indicated. DTRs mark the physical ends of the genome (bold vertical lines).

In the case of $\phi \mathrm{VaK}, \mathrm{VR} 2$ and VR3 are the most diverse compared to the other homogenous phage genomes. However, the vast majority of the changes are silent and do not translate into any differences in the predicted gene function at the amino acid level.

The detailed annotations for the 19 temperate bacteriophages are listed in the Supplementary Table S2. 


\subsection{Vibrio CRISPR Spacers in H20-Like Phages}

Although H20-like bacteriophages were isolated from distant and different locations, their genetic differences are minor. In order to assess the interaction of H20-like bacteriophages with Vibrio hosts in general, a matrix containing the CRISPR arrays from all the published Vibrio genomes was composed. Keeping the cut-off value of $>80 \%, 10$ CRISPR spacers from three different Vibrio species were found to match with the consensus genome of the H20-like phages (Supplementary Table S3), implying a Vibrio-H20-like phage contact at some point through evolutionary time. Furthermore, the mapping of H20-like phage genomes against the two publicly available CRISPR arrays of V. anguillarum strain PF7, led to 24 spacers matching with $>80 \%$ similarity. Eighteen of them were $>95 \%$ similar, whereas eight of them were $100 \%$ identical to genomic parts of the H20-like phages. The spacers matched against several regions in the phage, and were randomly scattered in the genome. Additionally, in the case of V. navarrensis (ATCC 51183), the spacer 21 matches 100\% with its corresponding part in the H20-like phage genome, whereas 9 more spacers mapped with $>80 \%$ similarity. In order to assess the presence of H20-like prophages in $V$. anguillarum, the genomes of the bacterial collection of $V$. anguillarum strains were analyzed. The sequences of $17 \mathrm{H} 20$-like prophages were bioinformatically detected as integrated in the 31 V. anguillarum genomes (Table 3).

Table 3. Bioinformatic analysis indicates the presence or absence of $\mathrm{H} 20$-like prophages in the genomes of 31 pathogenic $V$. anguillarum strains originated from several different aquaculture producing countries. n/a: not available.

\begin{tabular}{|c|c|c|c|c|}
\hline Stain Code & Origin & $\begin{array}{l}\text { Phylogenetic } \\
\text { Group }\end{array}$ & $\begin{array}{l}\text { H20-Like } \\
\text { Prophage }\end{array}$ & Reference \\
\hline DSM21597 & Norway & I & - & [51] \\
\hline 4299 & Norway & II & - & [52] \\
\hline HI610 & Norway & II & - & [53] \\
\hline $\mathrm{S} 22 / 9$ & Denmark & III & - & [54] \\
\hline $90-11-286$ & Denmark & III & - & {$[54,55]$} \\
\hline PF430-3 & Chile & IV & - & [36] \\
\hline PF4 & Chile & IV & - & [56] \\
\hline PF7 & Chile & IV & - & [56] \\
\hline A023 & Spain & $\mathrm{V}$ & $x$ & [57] \\
\hline $90-11-287$ & Denmark & V & $x$ & [55] \\
\hline $51 / 82 / 2$ & Germany & V & $x$ & [57] \\
\hline $\mathrm{T} 265$ & UK & $\mathrm{V}$ & - & [57] \\
\hline HWU53 & Denmark & $\mathrm{V}$ & $x$ & [57] \\
\hline $6018 / 1$ & Denmark & $\mathrm{V}$ & $x$ & [57] \\
\hline $91-8-178$ & Norway & $\mathrm{V}$ & $x$ & [57] \\
\hline $87-9-116$ & Finland & V & $x$ & {$[54,55]$} \\
\hline $91-7-154$ & Denmark & V & $X$ & {$[54,55]$} \\
\hline $601 / 90$ & Italy & V & $x$ & [54] \\
\hline $178 / 90$ & Italy & $\mathrm{V}$ & $x$ & [54] \\
\hline $9014 / 8$ & Denmark & V & $x$ & [54] \\
\hline $261 / 91$ & Italy & $\mathrm{V}$ & $X$ & [57] \\
\hline LMG12010 & $\mathrm{n} / \mathrm{a}$ & V & $x$ & [57] \\
\hline $87-9-117$ & Finland & $\mathrm{V}$ & $X$ & {$[54,55]$} \\
\hline BA35 & USA & V & - & [57] \\
\hline 775 & USA & $\mathrm{V}$ & - & {$[58,59]$} \\
\hline NB10 & North Baltic & V & $x$ & {$[49,60]$} \\
\hline VA1 & Denmark & $\mathrm{V}$ & $x$ & [36] \\
\hline $850610-1 / 6 a$ & Denmark & $\mathrm{n} / \mathrm{a}$ & $X$ & [57] \\
\hline VA2 & Denmark & $\mathrm{n} / \mathrm{a}$ & - & [36] \\
\hline VA3 & Denmark & $\mathrm{n} / \mathrm{a}$ & - & [36] \\
\hline VaKef & Greece & $\mathrm{n} / \mathrm{a}$ & $x$ & $\begin{array}{c}\text { Clinical } \\
\text { strain-Unpublished }\end{array}$ \\
\hline
\end{tabular}




\subsection{H20-Like Prophages Presence in V. anguillarum}

According to the phylogenetic tree that was constructed from the identified prophages and isolated temperate phages, five out of 17 prophages and three out of 19 free-living phages are forming two different small monophyletic groups. However, 11 out of 17 prophages and 15 out of 19 free-living temperate phages are clustered together in a genetically and statistically robust and homogenous taxon, independent of their origin. Bacteriophage $\phi \mathrm{VaK}$ is clustered together with the VA1 prophage forming a separate monophyletic taxon (Figure 5).

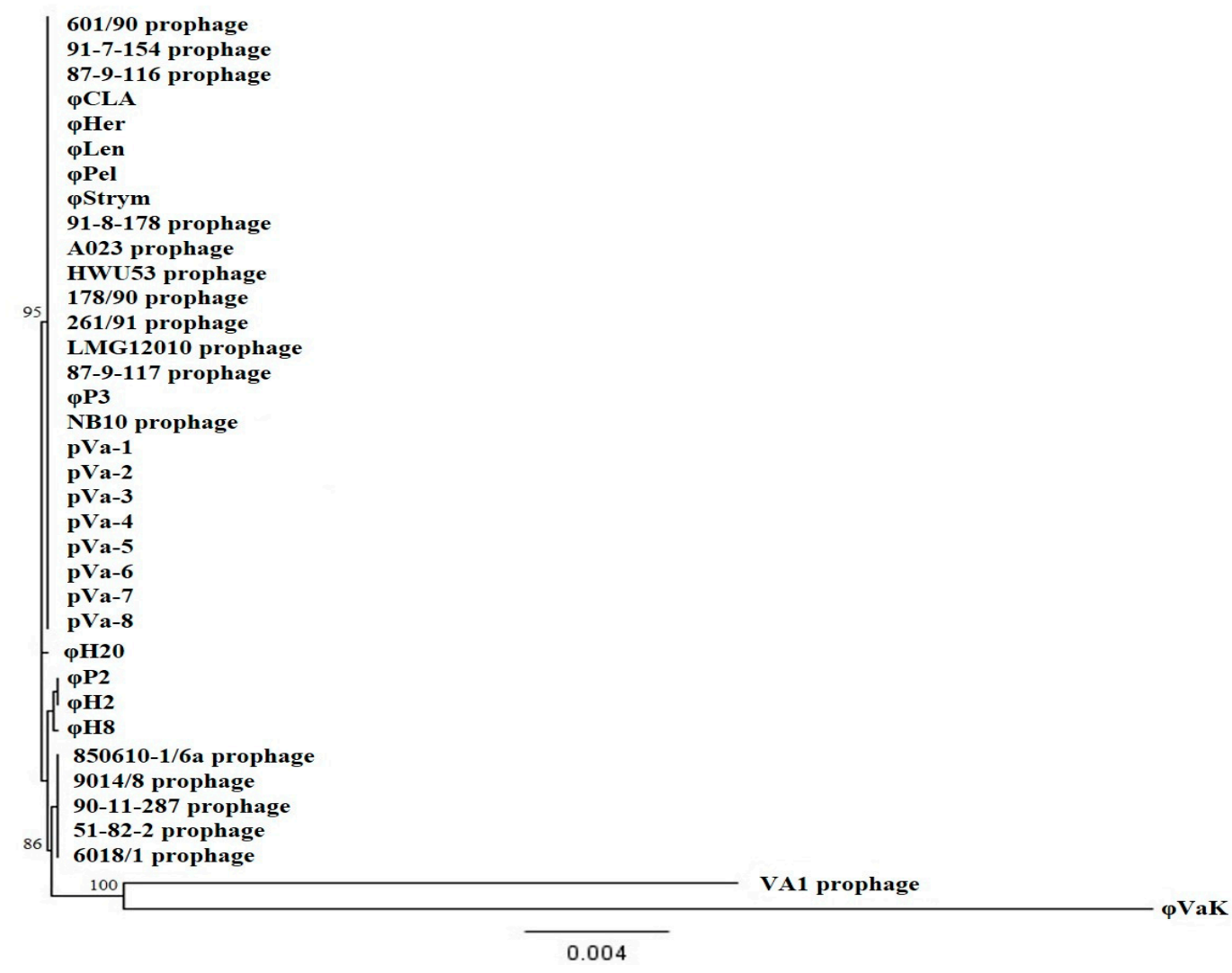

Figure 5. Phylogenetic tree (Neighbor-Joining method) based on the whole genomes of the 19 temperate bacteriophage isolates of the current study and 17 prophages which were bioinformatically detected in the genome of their V. anguillarum hosts. The branch labels indicate the percentage of statistical support.

The in vitro cell lysis experiment (Supplementary Figure S2) confirmed that the temperate bacteriophage $\mathrm{H} 20$ isolated as a free-living phage can be integrated in the host's bacterial genome. The PCR with specific primers performed on the isolated bacterial strains was positive in amplifying the three selected gene parts of the H20-like phages. In $28 \%$ of the bacterial host strains (14 out of 50), the bacteriophage $\phi \mathrm{H} 20$ was successfully integrated after $10 \mathrm{~h}$ of co-culturing.

\subsection{Distribution of H20-Like Phage on a Global Scale}

Free-living H20-like bacteriophages have been isolated from Denmark, Norway, Greece and Chile. Combining these data with geographical distribution of the Vibrio CRISPR spacers matches and the functional prophages contained in the V. anguillarum genomes, the $\mathrm{H} 20$-like bacteriophages seem to show a global scale distribution (Figure 6). 


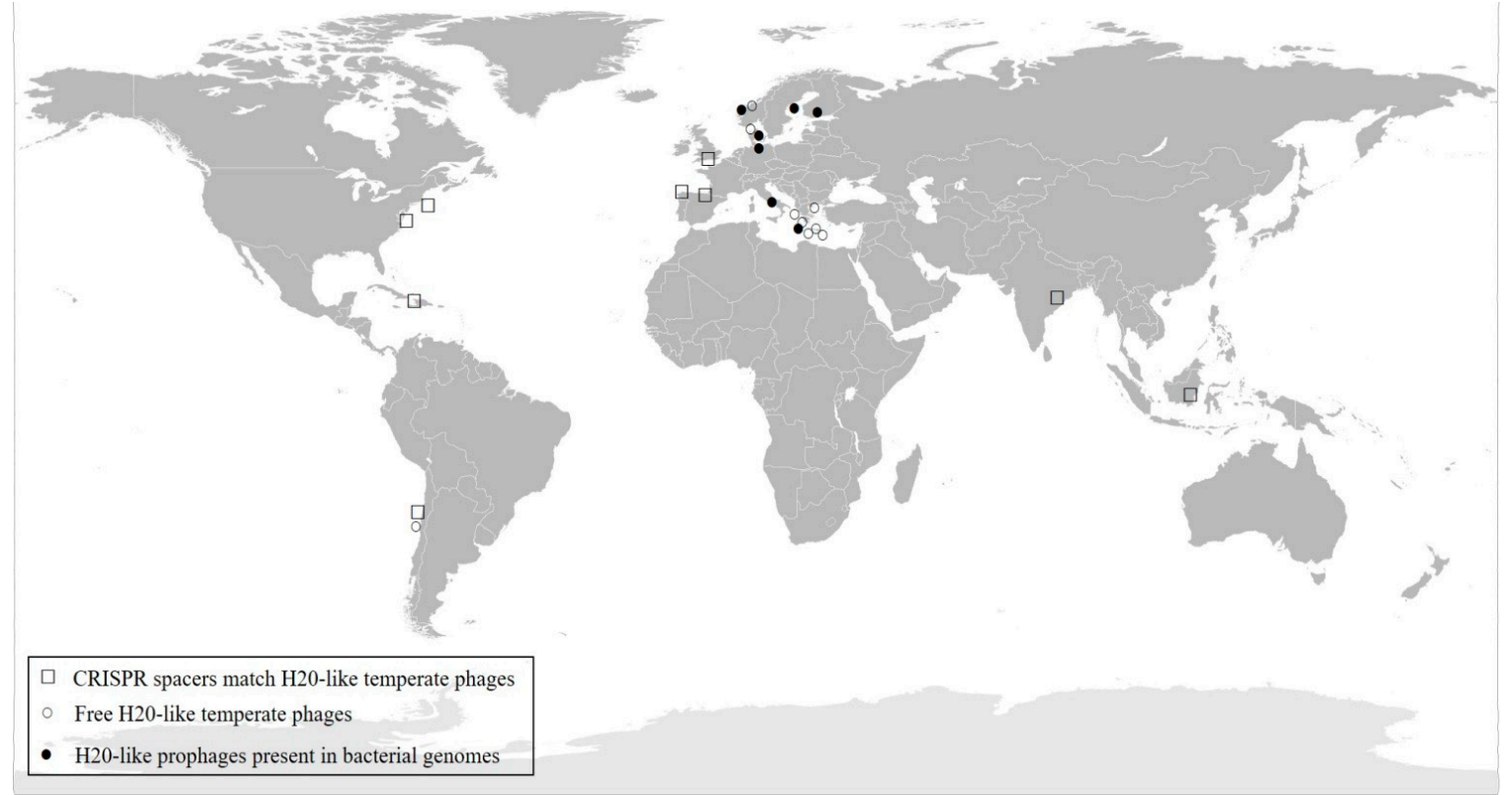

Figure 6. Distribution of H20-like phages on a global scale. The presence of the phage in the different locations was confirmed by: (a) isolating them as free phages from the environment $(\bigcirc)$; (b) bioinformatic detection of their presence as prophages in the bacterial host genomes (•); and (c) high similarity matches of the temperate phages with CRISPR spacers in the Vibrio genus ( $\square$ ).

\section{Discussion}

Several lytic Vibriophages have previously been sequenced and characterized in connection with their potential use as a strategy against vibriosis in aquaculture [61]. However, there are very few reports on temperate phages against non-cholera Vibrio strains $[15,62]$ and their potential importance for lateral transfer of virulence and metabolic capacities among other Vibrio pathogens $[11,20,63]$.

The H20-like phage genomes showed no similarity to available phage sequences in GenBank. However, all the phages displayed high genetic similarity with a sequence in in $V$. anguillarum strain NB10, which was then identified as a previously undetected prophage in genome of NB10 [49], and subsequently, in 17 other $V$. anguillarum strains. The most prominent differences between NB10 prophage and H20-like viruses were observed in the variable regions VR1, VR2 and VR3.

Among the H20-like phages cluster, $\phi \mathrm{VaK}$ showed the largest genetic differences. Most of the genetic differences were synonymous, leaving the encoded genes unaltered. However, the variations of $\phi \mathrm{VaK}$ in the VR1 may explain the differences in its host range, since even small changes in structural proteins such as minor tail proteins and tail fiber proteins may affect host range [64]. The bacterial host strain VaKef that was used for the isolation of $\phi \mathrm{VaK}$ was also different from the closely related BA35 and T265 and A023 that were used for isolating the rest of the H20-like Siphoviruses.

Phage tail length tape measure protein has a crucial role in phages' genome injection into the bacterial host [65]. Interestingly, the structure of this protein in H20-like phages resembled the structure of the channel forming toxin colicin Ia [66], suggesting a dual role for the phage tail length tape measure gene. Since only one molecule of colicin Ia is needed to kill a bacterial cell (single hit kinetics) [67], these pore forming toxins are lethal for the bacteria [68,69]. A temperate phage encoded colicin Ia could therefore potentially confer a fitness advantage to its host against competing bacterial strains but could also be lethal for its own host. Lytic activity of phage tail length tape measure protein has previously been reported in Staphylococcus aureus specific Siphovirus vB_SauS-phiIPLA35, where a lysozyme-like domain of the tape measure protein had muramidase activity able to lyse $S$. aureus cells [70]. 
The detection of N6-adenine methyltransferase gene in the H20-like phages may contribute to explaining their wide distribution, as it potentially interferes with the Restriction-Modification (RM) bacterial phage defense system [71,72] thus improving the infection efficiency of the H20-like phages. RM systems generally consist of a restriction endonuclease which cleaves invading phage dsDNA and a methyltransferase, which catalyzes the methylation of specific bacterial dsDNA sequences, protecting the hosts own DNA from enzymatic cleavage. The presence of methyltransferase in the H20-like bacteriophages indicated that these phages can methylate their own DNA to avoid degradation by the host's restriction enzymes. This finding is in accordance with other studies showing that the presence of virus-encoded N6-adenine methyltransferase can provide protection against restriction endonuclease activity [21,73]. However, the role of N6-adenine methyltransferase does not seem to operate solely as a counter defense mechanism to bacterial RM systems. Methyltransferases can also affect bacterial virulence [74] or function as transcriptional regulators by either activating or repressing bacterial genes [75,76]. N6-adenine methyltransferase was previously found in the temperate Vibriophage VHML where it was linked with the virulence of $V$. harveyi host strain upon integration [77]. Epigenetic control of gene expression through methylation is a powerful tool in prokaryotes emphasizing the potential influence of the H20-like phages in host functional properties. The presence of N6-adenine methyltransferase gene in $\mathrm{H} 20$-like phages genomes seems to be an important mutual benefit in the host-phage interaction which may promote coexistence. In general, methyltransferase-encoding genes are found in about $20 \%$ of the currently annotated bacteriophage genomes [78], supporting an important role of the gene for the phage-host interaction.

Examples of co-evolution of temperate bacteriophages and their bacterial hosts also includes phage-encoded prevention of infection by other phages by superinfection exclusion (Sie) [79]. The H20-like phages carry a repressor gene which genetically and structurally resembles the lambda temperate phage repressor. Such repressor proteins could potentially protect the lysogenized bacteria from similar superinfecting bacteriophages by blocking the expression of the lytic pathway genes [80,81] and this mechanism possibly confers repressor-mediated immunity to other H20-like phages in their $V$. anguillarum host.

Prophages have previously been shown to potentially affect fitness and metabolic properties in fish pathogenic Vibrios. For example, the temperate Vibriophage VHML decreased the nutrient uptake in lysogenized $V$. harveyi cells, through a generalized suppression of metabolic activity as a potential energy-saving mechanism under nutrient-limited conditions [82]. Further, evidence of phage-encoded hemagglutinin, which is potentially involved in virulence of $V$. pelagius $[63,83]$ and experimental verification of prophage-mediated virulence in $V$. harveyi [16] support that lysogenic conversion in Vibrios represents an important mechanism of adaptation to changing environmental conditions. The presence of functional genes in the H20 like-phages suggests that these phages may also represent a significant contribution to the phenotypic properties of $V$. anguillarum upon integration.

The tRNA ${ }^{A r g}$ that was found in the genome of H20-like phages has also been reported in other Siphoviruses [84] and encodes the amino acid codon AGA which is considered a rare arginine tRNA [85]. Rare codons are generally responsible for encoding transcriptional and translational properties that are distinct from those encoded by the prevalent arginine codons and therefore affecting the expression of regulatory genes [86]. In accordance with this, all four arginine amino acids which are encoded by repressor gene in the $\mathrm{H} 20$-like bacteriophages are translated by the rare codon AGA. This suggests that the tRNA in the H20-bacteriophages participates in the regulation of the expression of the repressor, and thus in the decision of lytic or temperate life cycle, implying also that there might be other reasons for phages to carry tRNAs beyond rare codon usage.

The isolation of phages and prophages belonging to the H20 group across large geographical scales and in marine environments with and without aquaculture activities suggests that these V. anguillarum phages are common and widespread in the marine environment. Further, the high levels of identity with spacers of the CRISPR systems detected in both V. anguillarum and in other Vibrio bacteria, indicated long term interactions between Vibrios and H20- like phages. This is in line with recent 
observations of susceptibility to specific phages in 36 isolates of the cosmopolitan Roseobacter-clade species, Rugeria mobilis obtained across the world's oceans covering large ranges in temperature, oxygen concentration and habitat (free-living, particle attached, sediment) [25]. These results suggest the co-existence of specific phages and bacteria on a global scale in groups of ubiquitous marine bacteria such as Roseobacter and Vibrio. This seems inconsistent with the perception of phage-host interactions as a driver of phage and bacterial co-evolution and diversification, as this mechanism would be expected to promote local diversification in response to selection for phage resistance in bacterial populations. The ability of phages to move across biomes have shown to result in a high viral diversity on a local scale, but relatively low diversity when examined globally [28,87]. In addition, different types of phages seem to show different distribution patterns as phages belonging to Myoviridae and Podoviridae have demonstrated specific geographical distribution, whereas Siphoviruses displayed a global distribution [88].

The distribution patterns of specific phages and hosts and the implications of phage-host interactions on evolution and diversification thus seems to vary across spatial scales and between groups of bacteria and phages. While the co-evolutionary dynamics of phages and hosts have traditionally been characterized in terms of selection pressures on host defense and phage infectivity, the mutualistic nature of the interaction between temperate phages and their hosts may select for co-existence rather than arms race dynamics [20]. The efficient lysogenization of susceptible $V$. anguillarum by temperate phage $\mathrm{H} 20$ and thus transfer of phage-encoded genes between bacterial strains demonstrated in the current study emphasizes the potential of H20-like phages for integration in their host genome and thus the dispersal of the phage genes in V. anguillarum. Consequently, efficient dispersal of phages and bacteria across large spatial scales in the marine environment and a selective advantage of the phage-host interaction by lysogenic conversion of the host may select for phage-host co-existence in the global ocean and thus contribute to explaining the currently observed large scale distribution of H20-like temperate phages and prophages.

Supplementary Materials: The following are available online at www.mdpi.com/1999-4915/9/5/122/s1, Table S1: Three sets of specific primers designed for picking a hypothetical protein, a structural protein gene and a terminase protein gene, respectively. Table S2: Detailed annotations for the 19 temperate bacteriophages. Table S3: Spacers. Figure S1: One step growth curves and phage adsorption curves, for bacteriophages $\phi H 20$, Va-3, $\phi C L A$ and $\phi P 3$. Figure S2: In vitro cell lysis experiment of bacteriophage $\phi \mathrm{H} 20$ against its bacterial host V. anguillarum strain BA35. Arrow indicates the sampling point.

Acknowledgments: The study was supported by the Danish Council for Strategic Research (ProAqua project 12-132390), the Danish Agency for Science, Technology and Innovation (INP Grant\# 5132-00014B) and by the Greek National Strategic Reference Framework 2007-2013 (co-funded by European Social Fund and Greek National Funds) FISHPHAGE project 131, www.gsrt.gr. We would like to thank the staff of Venøsund and Sogndal aquaculture units for providing us water samples and George Chalepakis and the staff of the Laboratory of Electron Microscopy of the University of Crete for the TEM work.

Author Contributions: Conceived and designed the experiments: P.G.K., N.R., P.K., M.M. Performed the experiments: P.G.K., N.R., D.C., J.J., J.J.M., C.K. Analyzed the data: P.G.K., N.R., D.C., M.M. Contributed reagents/materials/analysis tools: P.K., F.Z., M.M. Wrote the paper: P.G.K., N.R., M.M.

Conflicts of Interest: The authors declare no conflict of interest.

\section{References}

1. Takemura, A.F.; Chien, D.M.; Polz, M.F. Associations and dynamics of vibrionaceae in the environment, from the genus to the population level. Front. Microbiol. 2014, 5, 1-26. [CrossRef] [PubMed]

2. Thompson, F.L.; Iida, T.; Swings, J. Biodiversity of Vibrios. Microbiol. Mol. Biol. Rev. 2004, 403-431. [CrossRef] [PubMed]

3. Thompson, J.; Polz, M. Dynamics of Vibrio Populations and Their Role in Environmental Nutrient Cycling. In The Biology of Vibrios; Thompson, F., Austin, B., Swings, J., Eds.; ASM Press: Washington, DC, USA, 2006; pp. 190-203.

4. Frans, I.; Michiels, C.W.; Bossier, P.; Willems, K.A.; Lievens, B.; Rediers, H. Vibrio anguillarum as a fish pathogen: Virulence factors, diagnosis and prevention. J. Fish Dis. 2011, 34, 643-661. [CrossRef] [PubMed] 
5. Frans, I.; Dierckens, K.; Crauwels, S.; Van Assche, A.; Leisner, J.; Larsen, M.H.; Michiels, C.W.; Willems, K.A.; Lievens, B.; Bossier, P.; et al. Does Virulence Assessment of Vibrio anguillarum Using Sea Bass (Dicentrarchus labrax) Larvae Correspond with Genotypic and Phenotypic Characterization? PLoS ONE 2013, 8, 2-10. [CrossRef]

6. Rønneseth, A.; Castillo, D.; D’Alvise, P.; Tønnesen, Ø.; Haugland, G.; Grotkjaer, T.; Engell-Sørensen, K.; Nørremark, L.; Bergh, Ø.; Wergeland, H.I.; et al. Comparative assessment of Vibrio virulence in marine fish larvae. J. Fish Dis. 2017. [CrossRef] [PubMed]

7. Rodkhum, C.; Hirono, I.; Stork, M.; Di Lorenzo, M.; Crosa, J.H.; Aoki, T. Putative virulence-related genes in Vibrio anguillarum identified by random genome sequencing. J. Fish Dis. 2006, 29, 157-166. [CrossRef] [PubMed]

8. Naka, H.; Crosa, J.H. Genetic Determinants of Virulence in the Marine Fish Pathogen Vibrio anguillarum. Fish Pathol. 2011, 46, 1-10. [CrossRef] [PubMed]

9. Clokie, M.R.; Millard, A.D.; Letarov, A.V.; Heaphy, S. Phages in nature. Bacteriophage 2011, 1, 31-45. [CrossRef] [PubMed]

10. Wagner, P.L.; Waldor, M.K. Bacteriophage Control of Bacterial Virulence. Infect. Immnunity 2002, 70, 3985-3993. [CrossRef]

11. Davies, E.V.; Winstanley, C.; Fothergill, J.L.; James, C.E. The role of temperate bacteriophages in bacterial infection. FEMS Microbiol. Lett. 2016, 363, 1-10. [CrossRef] [PubMed]

12. Waldor, M.K.; Mekalanos, J.J. Lysogenic Conversion by a Filamentous Phage Encoding Cholera Toxin. Science 1996, 272, 1910-1914. [CrossRef] [PubMed]

13. Fasano, A; Baudry, B.; Pumplin, D.W.; Wasserman, S.S.; Tall, B.D.; Ketley, J.M.; Kaper, J.B. Vibrio cholerae produces a second enterotoxin, which affects intestinal tight junctions. Proc. Natl. Acad. Sci. USA 1991, 88, 5242-5246. [CrossRef] [PubMed]

14. Weynberg, K.D.; Voolstra, C.R.; Neave, M.J.; Buerger, P.; van Oppen, M.J.H. From cholera to corals: Viruses as drivers of virulence in a major coral bacterial pathogen. Sci. Rep. 2015, 5, 17889. [CrossRef] [PubMed]

15. Oakey, H.J.; Owens, L. A new bacteriophage, VHML, isolated from a toxin-producing strain of Vibrio harveyi in tropical Australia. J. Appl. Microbiol. 2000, 89, 702-709. [CrossRef] [PubMed]

16. Munro, J.; Oakey, J.; Bromage, E.; Owens, L. Experimental bacteriophage-mediated virulence in strains of Vibrio harveyi. Dis. Aquat. Organ. 2003, 54, 187-194. [CrossRef] [PubMed]

17. Hasan, N.A.; Grim, C.J.; Lipp, E.K.; Rivera, I.N.G.; Chun, J.; Haley, B.J.; Taviani, E.; Choi, S.Y.; Hoq, M.; Munk, A.C.; et al. Deep-sea hydrothermal vent bacteria related to human pathogenic Vibrio species. Proc. Natl. Acad. Sci. USA 2015, 112, E2813-E2819. [CrossRef] [PubMed]

18. Brüssow, H.; Canchaya, C.; Hardt, W.; Bru, H. Phages and the Evolution of Bacterial Pathogens: from Genomic Rearrangements to Lysogenic Conversion. Microbiol. Mol. Biol. Rev. 2004, 68, 560-602. [CrossRef] [PubMed]

19. Feiner, R.; Argov, T.; Rabinovich, L.; Sigal, N.; Borovok, I.; Herskovits, A.A. A new perspective on lysogeny: prophages as active regulatory switches of bacteria. Nat. Rev. Microbiol. 2015, 13, 641-650. [CrossRef] [PubMed]

20. Obeng, N.; Pratama, A.A.; van Elsas, J.D. The Significance of Mutualistic Phages for Bacterial Ecology and Evolution. Trends Microbiol. 2016, 24, 440-449. [CrossRef] [PubMed]

21. Murphy, J.; Klumpp, J.; Mahony, J.; O'Connell-Motherway, M.; Nauta, A.; van Sinderen, D. Methyltransferases acquired by lactococcal 936-type phage provide protection against restriction endonuclease activity. BMC Genom. 2014, 15, 831. [CrossRef] [PubMed]

22. Bochow, S.; Elliman, J.; Owens, L. Bacteriophage adenine methyltransferase: A life cycle regulator? Modelled using Vibrio harveyi myovirus like. J. Appl. Microbiol. 2012, 113, 1001-1013. [CrossRef] [PubMed]

23. Paul, J.H. Prophages in marine bacteria: dangerous molecular time bombs or the key to survival in the seas? ISME J. 2008, 2, 579-589. [CrossRef] [PubMed]

24. Spencer, R.G.M. Indigenous marine bacteriophages. J. Bacteriol. 1960, 614.

25. Sonnenschein, E.C.; Nielsen, K.F.; D’Alvise, P.; Porsby, C.H.; Melchiorsen, J.; Heilmann, J.; Kalatzis, P.G.; Lopez-Perez, M.; Bunk, B.; Sproer, C.; et al. Global occurrence and heterogeneity of the Roseobacter-clade species Ruegeria mobilis. ISME J. 2016, 11, 569-583. [CrossRef] [PubMed]

26. Thurber, R.V. Current insights into phage biodiversity and biogeography. Curr. Opin. Microbiol. 2009, 12, 582-587. [CrossRef] [PubMed] 
27. Kellogg, C.A.; Rose, J.B.; Jaing, S.C.; Paul, J.H. Genetic Diversity of Related Vibriophages Isolated from Marine Environments Around Florida and Hawaii, USA. Mar. Sci. Fac. Pub. 1995, 120, 89-98. [CrossRef]

28. Breitbart, M.; Rohwer, F. Here a virus, there a virus, everywhere the same virus? Trends Microbiol. 2005, 13, 243-293. [CrossRef] [PubMed]

29. Comeau, A.M.; Suttle, C.A. Distribution, genetic richness and phage sensitivity of Vibrio spp. from coastal British Columbia. Environ. Microbiol. 2007, 9, 1790-1800. [CrossRef] [PubMed]

30. Romero, J.; Higuera, G.; Gajardo, F.; Castillo, D.; Middelboe, M.; Garcia, K.; Ramirez, C.; Espejo, R.T. Complete Genome Sequence of Vibrio anguillarum Phage CHOED Successfully Used for Phage Therapy in Aquaculture. Genome Announc. 2014, 2, 2013-2014. [CrossRef] [PubMed]

31. Higuera, G.; Bastías, R.; Tsertsvadze, G.; Romero, J.; Espejo, R.T. Recently discovered Vibrio anguillarum phages can protect against experimentally induced vibriosis in Atlantic salmon, Salmo salar. Aquaculture 2013, 392-395, 128-133. [CrossRef]

32. Mateus, L.; Costa, L.; Silva, Y.J.; Pereira, C.; Cunha, A.; Almeida, A. Efficiency of phage cocktails in the inactivation of Vibrio in aquaculture. 2014, 424-425, 167-173. [CrossRef]

33. Castillo, D.; Alvise, P.D.; Xu, R.; Zhang, F.; Middelboe, M.; Gram, L. Comparative genome analyses of Vibrio anguillarum strains reveal a link with pathogenicity traits. mSystems 2017, 2. [CrossRef] [PubMed]

34. Comeau, A.M.; Chan, A.M.; Suttle, C.A. Genetic richness of vibriophages isolated in a coastal environment. Environ. Microbiol. 2006, 8, 1164-1176. [CrossRef] [PubMed]

35. Stenholm, A.R.; Dalsgaard, I.; Middelboe, M. Isolation and characterization of bacteriophages infecting the fish pathogen Flavobacterium psychrophilum. Appl. Environ. Microbiol. 2008, 74, 4070-4078. [CrossRef] [PubMed]

36. Tan, D.; Gram, L.; Middelboe, M. Vibriophages and their interactions with the fish pathogen Vibrio anguillarum. Appl. Environ. Microbiol. 2014, 80, 3128-3140. [CrossRef] [PubMed]

37. Hyman, P.; Abedon, S.T. Practical methods for determining phage growth paramenters. In Bacteriophages: Methods and Protocols, Volume 1: Isolation, Characterization and Interactions; Clokie, M., Kropinski, A., Eds.; Humana Press: New York, NY, USA, 2009; pp. 175-202.

38. Castillo, D.; Christiansen, R.H.; Dalsgaard, I.; Madsen, L.; Middelboe, M. Bacteriophage resistance mechanisms in the fish pathogen Flavobacterium psychrophilum: Linking genomic mutations to changes in bacterial virulence factos. Appl. Environ. Microbiol. 2015, 81, 1157-1167. [CrossRef] [PubMed]

39. Kearse, M.; Moir, R.; Wilson, A.; Stones-Havas, S.; Cheung, M.; Sturrock, S.; Buxton, S.; Cooper, A.; Markowitz, S.; Duran, C.; et al. Geneious Basic: An integrated and extendable desktop software platform for the organization and analysis of sequence data. Bioinformatics 2012, 28, 1647-1649. [CrossRef] [PubMed]

40. Delcher, A.L.; Bratke, K.A.; Powers, E.C.; Salzberg, S.L. Identifying bacterial genes and endosymbiong DNA with Glimmer. Bioinformatics 2007, 23, 673-679. [CrossRef] [PubMed]

41. Aziz, R.K.; Bartels, D.; Best, A.A.; DeJongh, M.; Disz, T.; Edwards, R.A.; Formsma, K.; Gerdes, S.; Glass, E.M.; Kubal, M.; et al. The RAST Server: Rapid Annotations using Subsystems Technology. BMC Genomics 2008, 9, 75. [CrossRef] [PubMed]

42. Overbeek, R.; Olson, R.; Pusch, G.D.; Olsen, G.J.; Davis, J.J.; Disz, T.; Edwards, R.A.; Gerdes, S.; Parrello, B.; Shukla, M.; Vonstein, V.; Wattam, A.R.; Xia, F.; Stevens, R. The SEED and the Rapid Annotation of microbial genomes using Subsystems Technology (RAST). Nucleic Acids Res. 2014, 42, 206-214. [CrossRef] [PubMed]

43. Kelly, L.A.; Mezulis, S.; Yates, C.; Wass, M.; Sternberg, M. The Phyre2 web portal for protein modelling, prediction, and analysis. Nat. Protoc. 2015, 10, 845-858. [CrossRef] [PubMed]

44. Phyre ${ }^{2}$. Available online: http://www.sbg.bio.ic.ac.uk/phyre2/html/page.cgi?id=index (accessed on 1 March 2017).

45. Laslett, D.; Canback, B. ARAGORN, a program to detect tRNA genes and tmRNA genes in nucleotide sequences. Nucleic Acids Res. 2004, 32, 11-16. [CrossRef] [PubMed]

46. Darling, A.C.E.; Mau, B.; Blattner, F.R.; Perna, N.T. Mauve: Multiple alignment of conserved genomic sequence with rearrangements. Genome Res. 2004, 1394-1404. [CrossRef] [PubMed]

47. Agarwala, R.; Barrett, T.; Beck, J.; Benson, D.A.; Bollin, C.; Bolton, E.; Bourexis, D.; Brister, J.R.; Bryant, S.H.; Canese, K.; et al. Database resources of the National Center for Biotechnology Information. Nucleic Acids Res. 2016, 44, D7-D19.

48. Grissa, I.; Vergnaud, G.; Pourcel, C. CRISPRFinder: a web tool to identify clustered regularly interspaced short palindromic repeats. Nucleic Acids Res. 2007, 35, 52-57. [CrossRef] [PubMed] 
49. Zhou, Y.; Liang, Y.; Lynch, K.H.; Dennis, J.J.; Wishart, D.S. PHAST: A Fast Phage Search Tool. Nucleic Acids Res. 2011, 39, 1-6. [CrossRef] [PubMed]

50. Holm, K.O.; Nilsson, K.; Hjerde, E.; Willassen, N.-P.; Milton, D.L. Complete genome sequence of Vibrio anguillarum strain NB10, a virulent isolate from the Gulf of Bothnia. Stand. Genomic Sci. 2015, 10, 60. [CrossRef] [PubMed]

51. MacDonell, M.T.; Colwell, R.R. Phylogeny of the Vibrionaceae, and Recommendation for Two New Genera, Listonella and Shewanella. Syst. Appl. Microbiol. 1985, 6, 171-182. [CrossRef]

52. Mikkelsen, H.; Schrøder, M.B.; Lund, V. Vibriosis and atypical furunculosis vaccines; efficacy, specificity and side effects in Atlantic cod, Gadus morhua L. Aquaculture 2004, 242, 81-91. [CrossRef]

53. Samuelsen, O.B.; Bergh, Ø. Efficacy of orally administered florfenicol and oxolinic acid for the treatment of vibriosis in cod (Gadus morhua). Aquaculture 2004, 235, 27-35. [CrossRef]

54. Pedersen, K.; Gram, L.; Austin, D.A.; Austin, B. Pathogenicity of Vibrio anguillarum serogroup O1 strains compared to plasmids, outer membrane protein profiles and siderophore production. J. Appl. Microbiol. 1997, 82, 365-371. [CrossRef] [PubMed]

55. Skov, M.N.; Pedersen, K.; Larsen, J.L. Comparison of Pulsed-Field Gel Electrophoresis, Ribotyping, and Plasmid Profiling for Typing of Vibrio anguillarum Serovar O1. Appl Environ Microbiol. 1995, 61, 1540-1545. [PubMed]

56. Silva-Rubio, A.; Avendaño-Herrera, R.; Jaureguiberry, B.; Toranzo, A.E.; Magariños, B. First description of serotype $\mathrm{O} 3$ in Vibrio anguillarum strains isolated from salmonids in Chile. J. Fish Dis. 2008, 31, 235-239. [CrossRef] [PubMed]

57. Austin, B.; Alsina, M.; Austin, D.A.; Blanch, A.R.; Grimont, F.; Grimont, P.A.D.; Jofre, J.; Koblavi, S.; Larsen, J.L.; Pedersen, K.; Tiainen, T.; Verdonck, L.; Swings, J. Identification and Typing of Vibrio anguillarum: A Comparison of Different Methods. Syst. Appl. Microbiol. 1995, 18, 285-302. [CrossRef]

58. Actis, L.A.; Fish, W.; Crosa, J.H.; Kellerman, K.; Ellenberger, S.R.; Hauser, F.M.; Sanders-Loehr, J. Characterization of anguibactin, a novel siderophore from Vibrio anguillarum 775(pJM1). J. Bacteriol. 1986, 167, 57-65. [CrossRef] [PubMed]

59. Kosters, W.L.; Actisp, L.A.; Waldbeserp, L.S.; Tolmaskyp, M.E.; Crosapfl, J.H. Molecular characterization of the iron transport system mediated by the pJM1 plasmid in Vibrio anguillarum 775. J. Biol. Chem. 1991, 23829-23833.

60. Rehnstam, A.S.; Norqvist, A.; Wolf-Watz, H.; Hagstrom, A. Identification of Vibrio anguillarum in fish by using partial 16S rRNA sequences and a specific 16S rRNA oligonucleotide probe. Appl. Envir. Microbiol. 1989, 55, 1907-1910.

61. Oliveira, J.; Castilho, F.; Cunha, A.; Pereira, M.J. Bacteriophage therapy as a bacterial control strategy in aquaculture. Aquac. Int. 2012, 20, 879-910. [CrossRef]

62. Williamson, S.J.; McLaughlin, M.R.; Paul, J.H. Interaction of the $\Phi H S I C$ virus with its host: lysogeny or pseudolysogeny? Appl. Environ. Microbiol. 2001, 67, 1682-1688. [CrossRef] [PubMed]

63. Thompson, F.L.; Klose, K.E.; Group, A. Vibrio2005: The First International Conference on the Biology of Vibrios. J. Bacteriol. 2006, 188, 4592-4596. [CrossRef] [PubMed]

64. Jacobs-Sera, D.; Marinelli, L.; Bowman, C.; Broussard, G.; Guerrero, C.; Boyle, M.; Petrova, Z.; Dedrick, R.; Pope, W.; SEA-PHAGES; et al. On the nature of mycobacteriophage diversity and host preference. Virology 2012, 434, 187-201. [CrossRef] [PubMed]

65. Cumby, N.; Reimer, K.; Mengin-Lecreulx, D.; Davidson, A.R.; Maxwell, K.L. The phage tail tape measure protein, an inner membrane protein and a periplasmic chaperone play connected roles in the genome injection process of E.coli phage HK97. Mol. Microbiol. 2015, 96, 437-447. [CrossRef] [PubMed]

66. Wiener, M.; Freymann, D.; Ghosh, P.; Stroud, R.M. Crystal structure of colicin Ia. Nature 1997, 385, 461-464. [CrossRef] [PubMed]

67. Kim, Y.C.; Tarr, A.W.; Penfold, C.N. Colicin import into E. coli cells: A model system for insights into the import mechanisms of bacteriocins. Biochim. Biophys. Acta - Mol. Cell Res. 2014, 1843, 1717-1731. [CrossRef] [PubMed]

68. Alonso, G. How bacteria protect themselves against channel-forming colicins. Int. Microbiol. 2000, 3, 81-88. [PubMed]

69. Penfold, C.N.; Walker, D.; Kleanthous, C. How bugs kill bugs: progress and challenges in bacteriocin research. Biochem. Soc. Trans. 2012, 40, 1433-1437. [CrossRef] [PubMed] 
70. Rodríguez-Rubio, L.; Gutiérrez, D.; Martínez, B.; Rodríguez, A.; Götz, F.; García, P. The tape measure protein of the Staphylococcus aureus bacteriophage vB_SauS-phiIPLA35 has an active muramidase domain. Appl. Environ. Microbiol. 2012, 78, 6369-6371. [CrossRef] [PubMed]

71. Luria, S.E. Host-induced modifications of viruses. Cold Spring Harb. Symp. Quant. Biol. 1953, 18, $237-244$. [CrossRef] [PubMed]

72. Nathans, D.; Smith, H.O. Restriction endonucleases in the analysis and restructuring of dna molecules. Annu. Rev. Biochem. 1975, 44, 273-293. [CrossRef] [PubMed]

73. Park, Y.; Kim, G. Do; Choi, T.J. Molecular cloning and characterization of the DNA adenine methyltransferase gene in Feldmannia sp. virus. Virus Genes 2007, 34, 177-183. [CrossRef] [PubMed]

74. Wion, D.; Casadesús, J. N6-methyl-adenine: an epigenetic signal for DNA-Protein interactions. Nat. Rev. Microbiol. 2006, 4, 183-192. [CrossRef] [PubMed]

75. Low, D.A.; Weyand, N.J.; Mahan, M.J. Roles of DNA adenine methylation in regulating bacterial gene expression and virulence. Infect. Immun. 2001, 69, 7197-7204. [CrossRef] [PubMed]

76. Portillo, F.G.-D.; Pucciarelli, M.G.; Casadesus, J. DNA adenine methylase mutants of Salmonella typhimurium show defects in protein secretion, cell invasion, and M cell cytotoxicity. Proc. Natl. Acad. Sci. USA 1999, 96, 11578-11583. [CrossRef]

77. Oakey, H.J.; Cullen, B.R.; Owens, L. The complete nucleotide sequence of the Vibrio harveyi bacteriophage VHML. J. Appl. Microbiol. 2002, 93, 1089-1098. [CrossRef] [PubMed]

78. Murphy, J.; Mahony, J.; Ainsworth, S.; Nauta, A.; van Sinderen, D. Bacteriophage orphan DNA methyltransferases: Insights from their bacterial origin, function, and occurrence. Appl. Environ. Microbiol. 2013, 79, 7547-7555. [CrossRef] [PubMed]

79. Van Houte, S.; Buckling, A.; Westra, E.R. Evolutionary Ecology of Prokaryotic Immune Mechanisms. Microbiol. Mol. Biol. Rev. 2016, 80, 745-763. [CrossRef] [PubMed]

80. Pope, W.H.; Jacobs-Sera, D.; Russel, D.A.; Peebles, C.L.; Al-Atrache, Z.; Alcoser, T.A.; Alexander, L.M.; Alfano, M.B.; Alford, S.T.; Amy, N.E.; et al. Expanding the diversity of mycobacteriophages: Insights into genome architecture and evolution. PLoS One 2011, 6, e16329. [CrossRef] [PubMed]

81. Berngruber, T.W.; Weissing, F.J.; Gandon, S. Inhibition of superinfection and the evolution of viral latency. J. Virol. 2010, 84, 10200-10208. [CrossRef] [PubMed]

82. Vidgen, M.; Carson, J.; Higgins, M.; Owens, L. Changes to the phenotypic profile of Vibrio harveyi when infected with the Vibrio harveyi myovirus-like (VHML) bacteriophage. J. Appl. Microbiol. 2006, 100, 481-487. [CrossRef] [PubMed]

83. Williamson, S.J.; Paul, J.H. Environmental factors that influence the transition from lysogenic to lytic existence in the HSIC/Listonella pelagia marine phage-host system. Microb. Ecol. 2006, 52, 217-225. [CrossRef] [PubMed]

84. Wang, J.; Jiang, Y.; Vincent, M.; Sun, Y.; Yu, H.; Wang, J.; Bao, Q.; Kong, H.; Hu, S. Complete genome sequence of bacteriophage t5. Virology 2005, 332, 45-65. [CrossRef] [PubMed]

85. Zahn, K.; Landy, A. Modulation of lambda integrase synthesis by rare arginine tRNA. Mol. Microbiol. 1996, 21, 69-76. [CrossRef] [PubMed]

86. Napolitano, M.G.; Landon, M.; Gregg, C.J.; Lajoie, M.J.; Govindarajan, L.; Mosberg, J.A.; Kuznetsov, G.; Goodman, D.B.; Vargas-Rodriguez, O.; Isaacs, F.J.; et al. Emergent rules for codon choice elucidated by editing rare arginine codons in Escherichia coli. Proc. Natl. Acad. Sci. U.S.A. 2016, 113, E5588-E5597. [CrossRef] [PubMed]

87. Sano, E.; Carlson, S.; Wegley, L.; Rohwer, F. Movement of viruses between biomes. Appl. Environ. Microbiol. 2004, 70, 5842-5846. [CrossRef] [PubMed]

88. Williamson, S.J.; Rusch, D.B.; Yooseph, S.; Halpern, A.L.; Heidelberg, K.B.; Glass, J.I.; Pfannkoch, C.A.; Fadrosh, D.; Miller, C.S.; Sutton, G.; Frazler, M.; Venter, J.C. The sorcerer II global ocean sampling expedition: Metagenomic characterization of viruses within aquatic microbial samples. PLoS ONE 2008, 3, e1456. [CrossRef] [PubMed]

(C) 2017 by the authors. Licensee MDPI, Basel, Switzerland. This article is an open access article distributed under the terms and conditions of the Creative Commons Attribution (CC BY) license (http:/ / creativecommons.org/licenses/by/4.0/). 